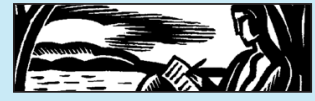

\title{
"Cheerful Angels Looking Down on Us": Parental Emotions in Diaries about the Illness and Death of Infants and Young Children (1780-1880)
}

\section{Leonieke Vermeer}

"At twenty minutes to eleven in the evening on the $10^{\text {th }}$ of March 1826, I was delivered of an eight-months baby, a well-formed son, whom we had hoped to call Isaäc Jacob, but the almighty God in His mercy and providence has taken that dear child into his glorious Kingdom [...]." 1 This is Hanna da Costa's diary description of the birth and death of her son who died after just six days. In the nineteenth century, the hope of being able to name a child before God took it away was often thwarted.

In the Netherlands around 1850 one in five children died in their first year of life; the mortality rate for children aged one to five years was not much lower. No more than half of children reached the age of eighteen. The death of children in their first year of life was mainly caused by gastro-intestinal ailments, inadequate hygiene and infectious diseases. Most infants who died were artificially fed; the use of dirty feeding devices, combined with the lack of proper milk storage and sterilization, were detrimental to the infants' health. Children in their second year of life often died from measles or whooping cough (Van Poppel and Beekink, 125-129; Engelen 2009, 103-104; Treffers 2008).

Since 1960, when French historian Philippe Ariès wrote L'Enfant et la Vie Familiale sous l'Ancien Régime (1960), published in English as Centuries of Childhood (1962), the high infant and child mortality rate has been used to support the claim that parental love did not exist before 1800-a claim later labelled as the "black legend". The high risk of mortality supposedly discouraged parents from forming an emotional attachment to their child. Or the opposite claim was made-that high child mortality was the consequence of a lack of parental love. The proponents of the "white legend", on the other hand, stated that children were always surrounded by love and parental concern. ${ }^{2}$ These extreme positions in 
the debate about parental love have since been abandoned and a more nuanced picture has emerged based on a wealth of source material: ego-documents such as diaries and autobiographies, elegies, paintings, photography, death circulars, letters of condolence and death notices (Sliggers 1998; Clarke 2000; R. Dekker 2000; J.J.H. Dekker 2010, 40-41, 70; Catalano 2015).

Evidence of parental concern for their children is vast and diverse, also in the centuries before 1870 , when the mortality rate began to fall. However, these emotional relationships within families need to be placed within their context, with an eye to the specific characteristics of the source material. The type of sources used to express parental emotions about the death of their children changes over time, just as the characteristics of sources themselves change. Although there are examples of first person sources from the early modern period that reveal emotions such as grief and mourning at the death of a child, other genres like elegies and funerary child portraits were more often used for this purpose. From the end of the eighteenth century both diary and autobiography became more common as means of expressing personal feelings (R. Dekker 2000, 134-138). The candid "journal intime", the diary as an instrument of self-knowledge and an outlet for emotions, emerged in the late eighteenth century, although similar writing practices can be traced earlier, mostly in pietist diaries (Jolly 2001, 334; Lejeune 2016, 139-193; Van Goltstein 1994, 41-42). Still, many nineteenth-century diaries revealed little intimacy and introspection and continued to be factual and impersonal (Baggerman and Dekker 2011, 465-467). Therefore, we should be cautious about generalising the shift towards more personal, intimate diaries. The diary is a heteroglossic genre which appears in a variety of shapes, both with regard to form and function. This inclusive approach has been a key feature of Philippe Lejeune's work on diaries: "every diary is interesting". He insisted on the importance of decoding the meaning of diaries within their specific cultural and historical context (Lejeune 2009, 134, 179).

The northern Netherlands are a place of particular relevance to study parental emotions in diaries. Firstly, because the origin of the modern concept of childhood has been traced in the Dutch Republic, a prosperous, highly urbanised country with an affluent middle class (R. Dekker 2000, 8). A remarkably continuous aspect in the history of the Dutch child has been that parents have been accused of indulging their children. From the early seventeenth century onwards there are accounts of foreign visitors in this manner. For example, the Frenchman Jean-Nicholas de Parival concluded in 1661 that the Dutch were "too permissive with children and did not punish them enough; that is why so many are 
ill-mannered, rebel against their parents and bring them great sorrow." (R. Dekker 2000, 6). It was also in the Netherlands that portraits of children appeared for the first time in large numbers-including deathbed and funerary portraits (Sliggers 1998).

Secondly, in the past decades all surviving Dutch "ego-documents", such as autobiographies, memoirs, diaries and letters, have been surveyed (Lindeman 2016). ${ }^{3}$ Historian Rudolf Dekker has studied a great number of these ego-documents and the way parents wrote about their children, stressing the changing memory strategies after 1800 (R. Dekker 1996). These Dutch sources, however, have scarcely been the subject of study with respect to parental emotions about the illness and death of a child and thus far have not been put in an international perspective of the history of emotions (R. Dekker 2000; Jalland 1996; Blauvelt 2002). ${ }^{4}$

This article focuses on eight Dutch diaries of parents from the period 1780-1880, a time when child mortality was still high, but when there was also growing concern for the needs of the child. Moreover, it was a period in which diaries became more important for the articulation of feelings, although, as pointed out above, one should be aware of generalising this development. The diaries I examine in this article have been selected because they give insight into parental emotions. Six diaries are "model sources", because the diarist writes about the loss of a young child. As additional sources to add nuance, I also discuss two diaries of parents who lost a young child but did not write about it. ${ }^{5}$ The discussion of eight diaries from different persons and contexts in the Netherlands in the scope of this article is exploratory; each diary would deserve more indepth study.

My focus is on parental emotions upon the illness and death of infants and young children (up to about four years of age). Other studies have suggested that the older the age at which a child died, the stronger the emotions (Bakker 2006, 124). Therefore, it is of particular interest if and which emotions were felt with the loss of infants and young children. How were childhood illness and death described in diaries? To what extent do diaries reveal emotions when children became ill and died (sometimes together with their mothers in childbirth)? What "silences" do we find in the sources and how can we interpret them?

Reconstructing emotions on the basis of diaries is a complex matter. It is difficult, if not impossible, to discover what parents "really" felt. Diaries are not about the experiences themselves, but about described experiences, in which narrative strategies, rhetorical conventions and cultural norms play a major role (Vermeer 2017). The diary can be seen as "the intersection of stimulating or oppressive societal conventions 
and the diarist's personal reactions to and interventions in cultural reality". It is a form of writing especially suitable for articulating emergent "structures of feeling", a term of Raymond Williams that refers to social experience which is still in process (Millim 2016, 22). The concept of "emotion work", developed by sociologist Arlie Russell Hochschild and applied more recently in the historical study of emotions as "practice," provides a fruitful approach to the study of emotions in first person writings (Hochschild 1983; Blauvelt 2002, 577; Ruberg 2005, 94-95; Scheer 2012; Millim 2016, 3). "Emotion work" involves the efforts required to satisfy cultural norms that prescribe which emotions should and should not be felt and displayed. Thus, there are conventional "reasons for consolation" in times of mourning; in the nineteenth century, these were still largely governed by religious faith (Sturkenboom 1990, 90-103). Therefore, the main question of this article is: how do Dutch diaries (1780-1880) of parents make visible the "emotion work" surrounding child illness and mortality?

Since literacy was particularly high in the Netherlands, individuals from an unusually broad range of social classes recorded their experiences. Still, people who were literate-and those who wrote diaries-were more often rich than poor. They were more likely to live in cities than the countryside, were primarily Protestant and usually male. As a consequence, far fewer women's diaries have survived than men's. From the late fifteenth to early nineteenth century, womens' diaries accounted for ten percent of all diaries. Although the number of diaries rose exponentially in the nineteenth century, the ratio stayed much the same (Dekker 1999, 269; Vandezande and Matthijs 2009, 72). To what extent gendered archival practices have also contributed to this imbalance, is a question that still deserves more scholarly attention (Schwartz and Cook 2002, 16; Hallgrimsdottir 2013). The ratio is also reflected in the selected sources of this article; two of eight diaries were written by women. Although the female side of the story is represented less fully, I will still try to make some suggestions regarding the differences between the "emotion work" of men and women.

\section{“THIS UNHAPPY EVENT HAS MOST AFFECTED MY WIFE"}

In earlier centuries too, the death of young children was a sad and incomprehensible event for parents. We need only read the many poems written about children who died, such as "To a deceased child" (1840) by minister and poet Nicolaas Beets, who lost five of his fifteen children at a young age: 
Many a tear has been shed for you,

Dear child, who we buried in the damp sand

But do you still sometimes look down on us, grieving,

Now that you are a cheerful Angel with God? ${ }^{6}$

While faith could offer consolation, it was also tested by the death of young children. As mentioned above, before 1800 diaries were not the conventional outlet for expressions of grief and mourning. Death poems, death circulars, letters of condolence and deathbed testimonies of children give us a better idea of the "reasons for consolation" and the conventions that applied to the display of emotions. Prior to 1800 people were expected to do their utmost to master their emotions. For the more educated, the ancient Stoics were a model in line with the Christian ideal of resignation (R. Dekker 2000, 132-138). In practice, not everybody could hold to this ideal, as for example is revealed clearly by religious deathbed-accounts of children in which emotional expressions of a highly personal and intimate character show intense parental affection and sorrow (Groenendijk et al. 2010). Gradually the prescribed Christian-stoic attitude towards death came under discussion. The display of grief became more common, although men were expected to exercise greater self-control than women (Sturkenboom 1990, 90-98; Clarke 2000, 68; Ruberg 2005, 220, 223). How were these conventions manifested in diaries in which parents wrote about the loss of young children?

Sigismund van Heiden Reinestein (1740-1806), chamberlain to stadholder William V and bailiff of Drenthe, barely writes about personal events in his diary. An exception occurred in 1780 when he recorded the illness and death of his four-year-old son Charles. On 9 August the child had fits, but bloodletting and the application of leeches were to no avail and the child died an hour later, in his fourth year. Van Heiden Reinestein writes more about his wife's emotions than about his own grief: "We are deeply saddened and this unhappy event has most affected my wife, to whom this child was particularly attached." On 10 August he notes: "The loss of my child is a cause of great sorrow to my wife." "But the fact that he did not get around to keeping a "neat copy" of his diary for months after this event suggests that he himself was also distraught - although his many duties as chamberlain may have been partly the reason (Van der Meer, Van de Pol and Bos 2007, xxiii).

Another diary in which emotions are not so clearly detectable is the "Kroniek van de familie" (family chronicle) of Reneke de Marees van Swinderen (1764-1848), a solicitor in the northern town Groningen. His diary begins as a typical example of a family record book that maintained 
a kind of register: a chronological list of the births, marriages and deaths of family members. Such records usually contained few expressions of feeling (R. Dekker 1995, 207). Gradually, the entries become longer. In 1788 he wrote about the death of his newborn son:

on the $17^{\text {th }}$ of December my wife thankfully gave birth to a son, who appeared quite healthy at birth, then on the sixth day had such violent fits that he succumbed on the $7^{\text {th }}$ day, being the 24 December. We therefore had the misfortune to lose this child again, only 8 days old. He is buried in the Aa church $[\ldots]$. After 6 weeks my dear wife had recovered once more and attended evening service $[\ldots] .^{8}$

In other diaries too, there is often mention of the mother's resumption of "churchgoing" as a sign of recovery after a difficult birth. When we compare this entry with the separate description on two pages of the death of his wife Meinardina Adriana Lohman in 1812, this last account is much longer, contains more medical details and is more emotional. It ends with his hope to see her again in a better, eternal life.

From the end of the eighteenth century there was more scope for emotions in diaries. The "journal intime" of Willem de Clercq is one of the most voluminous nineteenth-century diaries-it contains some 13,000 pages. De Clercq was poet and leader of the Réveil, an orthodox Protestant revival movement. In 1824 he gives a lengthy and emotional description of the death of his one-year-old son Paultje from whooping cough. When De Clercq discovered how serious the situation was, he decided to have the child baptised himself, because he did not want to wait until Paultje was eighteen-an age the little boy would never reach. ${ }^{9}$ De Clercq hesitated at first, because he feared people's disapproving reactions, but after Paultje was baptised, he found comfort in the thought that "as an angel, he may one day enlighten our dying." ${ }^{10}$

De Clercq's diary sheds light on the differences between the conventions that applied to men and to women when it came to displaying emotions at the death of a child: "It was terrible \& the dear child appeared to be dying. We sat there with him. A woman in these cases is blessed, she is where she should be, suffering and giving inspiration, a thousand and one things to attend to, a man sits there so wretchedly." ${ }^{11}$ The other members of his household "screamed and shouted" when the child died, but not everyone reacted so emotionally. After the child died, De Clercq's uncle Walrave Van Heukelom paid a visit: "Uncle van Heuk came too $\&$ reasoned with a masculine warmth \& strength, especially with respect to Lina." 12 This image of strong, rational men and suffering, emotional women, however, is too stereotypical and does not do justice to the more diverse historical picture. 


\section{"A FEW MORE MOMENTS AND HE IS NO MORE"}

The image of the remote nineteenth-century father who was barely involved in the upbringing of his children has since been modified by historians. Although fathers usually spent less time with their children than mothers did because of work and public duties, they were often very much involved with and close to their children (Tosh 1999, 93-100, 198199; Stavenuiter 1998, 22-26; Koning 2014, 144, 151). There are many examples of men who not only responded rationally, "with a masculine warmth \& strength" to the death of a child, but who were very distraught and emotional. As well as the diary of De Clercq himself, the diary of Hendrik Kikkert, a Vlaardingen shipowner and herring merchant, is a poignant case in point.

Hendrik and his wife Cornelia had ten children, two of whom died in their first year of life. Kikkert's diary shows that men too were very preoccupied with their children's welfare and displayed emotions when a young child died. He writes about the herring trade, the state of "the Fatherland", the "crazy liberals", and "the state of prosperity of my Household". ${ }^{13}$ His youngest child Cornelis, "a gentle, yet remarkably astute and lovable child", was often ill and in early 1831 he was the cause of many sleepless nights, such that Kikkert sometimes had to interrupt his diary writing or, to his regret, not get around to it at all. Cornelia's condition after the birth of Cornelis was also worrying. She had problems with an "ailment in her head" and "severe and painful cramps". She gradually recovered and was able to "go to church" once more, but a few weeks later all the children and his wife were once again confined to bed with heavy colds. In early March she was "very indisposed, and on the point of a nervous depression." ${ }^{14}$ Did Cornelia suffer from what today is called a postnatal depression?

On 24 February 1836 Hendrik noted in his diary that he had not written for three years; not out of indifference, but through lack of time. Nonetheless, he did want to resume writing again, and he also gave the reason why: "I would like to pour out my heart onto this paper again-so that by reading it again later I may enjoy or find comfort in it."15 Kikkert writes retrospectively that, among other things, Cornelis caught cholera in 1834 but had survived. Kikkert considered himself fortunate because divine providence had bestowed so many blessings upon him. "Our seven children are all still alive, although I am now watching over Mietje and Keetje [his two daughters aged five and two years], both of whom are sick with the measles, which Cornelis also suffered from some days ago."16 Hendrik, the seventh child, named after Kikkert himself, was born after a successful delivery.

Two months later, on 26 April 1836, the tone is very different. 
There I sit, next to the death bed of my youngest darling Hendrik. Ten weeks ago today God's love sent us, in him, a most beautiful and healthy child. For some weeks all was well, until 14 days ago and especially in the last 2 days, he began to decline and waste away, probably as a result of some defect in his intestines or heart, and now he lies lingering the whole evening:- - there lies that beautiful flower, the apple of our eyes, the darling of us all-touched by the cold hand of death, a few more moments and he is no more. ${ }^{17}$

This passage is remarkable, not just because of the emotions shown, but also because Kikkert wrote in the present tense. This makes it seem as though the experience and the description are occurring at one and the same time. From a practical point of view alone, this is difficult to imagine. From the fact that Kikkert already predicts the sad outcome-"a few more moments and he is no more"-and from the passage's conclusion, we can also gather that he was writing shortly after his son's death: "I have just closed his eyes, he has died-his good mother is worn out-asleep. I will go and wake her so that we can weep and pray together-and above all to thank God for all the good things we still have." 18 Although Kikkert probably started writing shortly after his son's death, he evokes the incident in the present tense. He is "writing to the moment", a form used in letter writing as well. It also resembles a direct, internal monologue, a narrative technique for representing consciousness that was increasingly used in novels at that time (also in the form of a soliloquy) ${ }^{19}$ In this way he gives an immediacy to his feelings.

Besides this narrative technique that is remarkable for a diary, Kikkert's account reveals the prevailing conventions for emotional display. He uses biblical imagery, such as the reference to his son as "that beautiful flower" (flowers in the Bible symbolise delicate life and beauty) and "the apple of our eyes" (Deuteronomy 32.10). He addresses the dead child directly, something we also encounter in many elegies to children: "Loved child! I look after You in Eternity, I weep for You as a father, Your death hurts my heart [...]." ${ }^{20}$ He consoles himself with the reassurance that those who died young had less opportunity to sin; a conventional reason for consolation, evident in books with Christian-stoic codes of conduct concerning resignation and pietist testimonies of children who died young (Groenendijk and Van Lieburg 1991; Vanmeenen and Havermans 2011, 6). Kikkert expresses this logic as follows: "I resign myself to God's wise and loving rule. In a few moments your pure and innocent child's soul will ascend to Heaven to be with Jesus the children's friend-with God, your and my Father, and then you will be forever blessed." There the child will ensure that the bereaved family will be supported in difficult times: "O! how many times will you perhaps look down on us with love, pray for us if we are threatened by suffering or disaster or temptations." 21 
Another conventional reason for consolation in Kikkert's account, that also can be found in $18^{\text {th }}$ and $19^{\text {th }}$ century books on etiquette, letters and in De Clercq's diary as well, is the hope of seeing one another again after death (Ruberg 2005, 221; Sturkenboom 1990, 95; Jalland 1996, 310). "That the thought of you my precious Child and the steadfast hope of seeing you again in Blessed Eternity-may never leave me, and now-farewell then darling-farewell until Eternity." 22

\section{“THIS STRUGGLE WAS VERY GREAT FOR ME”}

There is no diary of Kikkert's wife Cornelia. Only indirectly, from his comments about her as a good, but exhausted and unstable mother, can we gather something about her state. This is also the case in the diary of the minister Abraham Rutgers van der Loeff. When his one-and-a-halfyear-old daughter Ellegonda ("Gonnetje") dies in 1841, he gives a detailed description of the ineffective cure of leeches after which the child almost succumbs, the following slight recovery and finally the death choking of the child: "with every breath and raising eye the heart of the parents was also choking." ${ }^{23}$ As the conventions prescribed, he and his wife try to remain calm and devout. Abraham is satisfied that he succeeds in staying resigned even at the burial of the child, where his wife is not present. She stays home with some good friends, where Abraham finds her "still calm and devoutly reasoning and we had some useful and devotional conversations." ${ }^{24}$ The fact that mothers in the $17^{\text {th }}$ and $18^{\text {th }}$ century rarely attended the funerals (or baptisms) of their children has been interpreted as a sign of indifference. This view has been corrected by taking into account that rites of passage were traditionally regulated by conventions that proscribed or limited participation of parents (Wilson 1984, 188-189).

Until now, we have only witnessed the perspective of the fathers and husbands and their interpretations of the emotions of the mothers and wives. The diary of Hanna da Costa offers a rare look at the female experience of child illness and death. Hanna was the wife of Isaäc da Costa, one of the leaders of the previously mentioned Réveil movement. She went through eighteen pregnancies, had nine miscarriages and gave birth to nine children. Five of her nine children died at a young age. Isaäc Jacob died in 1826, just six days old. Religious resignation predominates in the description of his death: "the mighty God in His mercy and providence has taken that dear child into His glorious Kingdom." She even refers to a "blessed childbirth" and thanks God for "His special deliverance and restoration." ${ }^{25}$

When her two-year-old daughter Esthertje dies in 1830, she clearly has greater difficulty deriving comfort from her faith. Teething, as so often recounted in diaries, was a critical time, and was accompanied by high 
fever and fits. Hanna sang psalms at Esthertje's bedside, her husband Isaäc said a prayer. A doctor was summoned, but a warm bath and the application of sourdough to her calves was powerless to help. "The Almighty had chosen this moment [...] This struggle was very great for me, before I was able to surrender this precious child."26 She eventually resigns herself to divine mercy. "Gentle and majestic [heerlijk] was her passing." Here, "heerlijk" means "in the name of God". This emphasis on a gentle and calm end was one of the conventions that we also find in death circulars from this period (Ruberg 2005, 220; Jalland 1996, 52). And yet Hanna concludes her description with a comment about how hard it is to resign herself. She knows that she should have a "submissive and quiet spirit" and should not "rebel" against God-these were the rules of conduct for mourning-but "the flesh struggles against the spirit". Feeling and showing emotions according to the rules were two different things; "emotion work" was needed to bring them into alignment.

Hanna had to fight a similar battle in 1839, again over a two-year-old daughter also named Esthertje. A fall, while in the care of the nursemaid, proved fatal. A few days after the fall the child's right side was "attacked". Once again the medical profession-six different doctors were called in-was unable to provide meaningful assistance. Despite a footbath, sourdough, a "very lukewarm bath" and 22 leeches, Hanna comments: "Help from people is to no avail". Here too she ends her description with a struggle between comfort and resignation through faith on the one hand-"I imagine her as a floating cherub"-and admitting feelings about "the pain of her loss" on the other. She finds it hard to see the nursemaid again, but this too she overcomes with God's help. The nursemaid is allowed to stay.

\section{SILENCES}

Hanna da Costa's diary is in line with the earlier mentioned assumption that the older the age at which a child dies, the stronger the emotions. I have confined myself here to passages about the death of her young children, but this finding is also revealed in the lengthy comments about the illness and death of her nineteen-year-old daughter Hanna. After a description of the deathbed, a silence follows in the form of an empty page. ${ }^{27}$ Was she speechless with sorrow? Did she lack the energy to write? This is plausible, because she writes: "The many visits, letters, postcards were sometimes comforting, but also very exhausting." ${ }^{28}$ Did she want to fill the page later with an account of the final days? Definitive answers are impossible, but it is important to take these kinds of silences into 
account-therefore it is always necessary to study the original manuscript, because silences such as empty or torn-out pages, crossed-out lines and symbols often do not appear in the edited versions of diaries.

Lengthy, emotional descriptions of the illness and death of young children, as found in the diaries of Willem de Clercq, Hendrik Kikkert and Hanna Da Costa, do not appear in all diaries. Emotions sometimes have to be inferred from silences. Philippe Lejeune has stressed the importance of implicit information, gaps and self-censoring in diaries (Lejeune 2009, 132). It is important to interpret silences as part of the narrative itself (Vermeer 2017). Therefore, as additional sources to add nuance, I wish to discuss two other diaries of a father and a mother who we know lost a young child but did not write about it. We should exercise caution here, however. Given the earlier mentioned conventions and the difference between experiencing something and describing it, it is hard to draw conclusions about emotions based on what is written. But drawing conclusions about what is not recorded is, if possible, even more complicated. Elisabeth Clarke has shown that silences in English, $17^{\text {th }}$ century women's manuscript journals on the deaths of children were the result of male editing and control within orthodox religious discourse (Clarke 2000). But silences can have many different causes. Did the diarist not write about it or has that part not survived? Did the author perhaps intend to fill the empty page later? Are crossed-out passages, torn-out pages or the diary's destruction the result of self-censorship, control of a husband or wife, or intervention by descendants? Or are silences in diaries a sign of the diarist's emotions that he or she could not articulate? This last possibility may apply to the following two diaries, bearing in mind the justmentioned reservations in the form of other, plausible reasons for these silences.

Four infants died in the family of Amsterdam banker Johannes Deodatus Waller. In 1841 and 1848 he wrote at length about two daughters-Ida (Daatje) and Aletta Maria-who survived. But he wrote almost nothing about the death of the four babies; only from the comments about Ida in 1841 do we know that the four children he had lost during the five previous years had died of a "similar" illness. As was customary in such sources, the disease or diagnosis is not mentioned. Waller does, however, describe symptoms such as shortness of breath, hawking and looking "deathly pale". He thought the problem lay with the breast-feeding and decided to engage a new wet nurse, after which Ida recovered a little. The description ends abruptly: "the child is growing very thin." These notes, written on eight loose pages with two small round holes at the edges of the fold, appear to have been part of a larger notebook. After a seven-year silence, the writing begins again in 1848, once again with an illness of Ida's. Ida, 
who as a child so often hovered between life and death, eventually reached the ripe old age of 85; this would explain why the notes about her have survived-she was probably able to exercise influence over her legacy. ${ }^{29}$

The second additional source is the diary of Gertje Woutera van Slooten-Verwijs, wife of an alderman in the northern village of Dokkum, who had eleven children. She too wrote in her diary about the children who survived, but not about the dead infant Adrianus (May 1867) and a stillborn son (November 1875). When she had another son in 1877 , she again called him Adrianus. It was clearly not unusual to give a child the same name as a son or daughter who had died, as we also saw earlier with Esthertje da Costa. With this Adrianus, we see the beginnings—in 1877of the first Dutch "baby diary" I know of (in which mothers record all the significant events in a baby's life, such as breastfeeding, weaning, teething, the first solid food, first steps, first words, christening, et cetera). ${ }^{30}$ Hanna da Costa had also recorded many of these events about her children, but she didn't do so systematically and she didn't keep a diary solely for that purpose. On 24 August 1877, when Adrianus was eight months old, his mother wrote: "His fourth tooth. He is cheerful and looks very healthy, goes outside as much as possible each day." 31

A happy and healthy baby-this phenomenon became increasingly common from this time on. From 1870 child mortality gradually began to decline as a result of epidemics dying out, improved protection against these diseases and an overall improvement in the economic and cultural conditions (Van Poppel and Ekamper, 22).

\section{CONCLUSION}

Parents have always experienced emotions upon the illness and death of children, but these are not timeless. The way in which parents express and describe this profound event changed, depending on the prevailing cultural norms and conventions. Before 1800 parents were more likely to use other means than diaries to express emotions of grief and mourning, such as funerary portraits and poetry. In family record books, such as the one of Reneke de Marees van Swinderen, deaths of children were noted in a brief and matter-of-fact way. Reticence in bereavement, however, is no guide to the depth of loss felt. We have to take into account both the appropriate genres for the expression of emotions and the conventional forms of mourning.

After 1800 more scope was created for the display of emotions and diaries were increasingly used as means for expressing these emotions. These emotions, however, were conventionally proscribed or limited as a result of the prevailing Christian-stoic attitude towards death. This attitude was 
clearly visible in the selected diaries, although they also show how difficult this convention was in practice. Both fathers and mothers described feelings of sorrow for their children who died young. The sources studied here-most notably the diary of Hanna da Costa-confirm the notion that women had to do more intensive "emotion work" in order to bring their feelings in line with cultural and religious norms (Blauvelt 2002, 586). Hanna da Costa tellingly refers to her struggle to find the religious resignation expected of her. Male diarists, like Van Heiden Reinestein, De Clercq, Kikkert and Rutgers van der Loeff, wrote accounts which apportioned emotional responses between husband and wife, although we should be aware that this may not have been the actual pattern of emotions that the two parents felt and displayed.

In all the diaries, for both men and women, silences are important. Not only what is recorded, but also what is not recorded can-with reservations-shed light on emotions. As is logical, more descriptions have survived of children who lived. Although there are also surviving descriptions of children who died-think of Hendrik Kikkert, where description and experience were so closely intertwined-the diaries are just as often silent and we have to rely on other sources and, in their absence, our imagination to give meaning to these silences. However, such an attempt to "fill in the gaps" should be made with restraint, as Philippe Lejeune argued in his essay "The Diary as 'Antifiction'”, with regard to the genre of "imaginary diaries" of real people: "Clever people who claim to know what someone else would write in their heart of hearts are apt to come out looking naïve." (Lejeune 2009, 209). It is precisely its incompleteness and fragmentation that gives the diary its distinct, unfinished quality which makes it attractive as a historical source, especially for the history of emotions.

\section{WORKS CITED}

\section{Primary sources}

\section{Archival sources}

Diary of Abraham Rutgers van der Loeff, http:/ /www.rutgersvanderloeff.nl/dagboek/html/ index.html (accessed 25 May 2018).

Diary of Hanna da Costa-Belmonte, Special Collections of the University of Amsterdam, ref. nr. RA H: XVIII.

Diary of Hendrik Kikkert, Gemeentearchief Vlaardingen, HS 897.

Diary of J.D. Waller, met verslag van de ziekte van zijn kindje, 1840-1849, Stadsarchief Amsterdam, Archief van Waller-Pierson, toegangsnr. 1092, inv.nr.14.

Diary of Willem de Clercq, http://resources.huygens.knaw.nl/retroboeken/declercq (accessed 25 May 2018).

Kroniek van de familie, 1756-1848, aangelegd en bijgehouden door Reneke de Marees van Swinderen van Allersma 1827, vervolgens bijgehouden door zijn zoon Wicher Meynart de 
Marees van Swinderen, 1818-1848, Groninger Archieven, Familiearchief Van Swinderen en De Marees van Swinderen, toegangsnr. 552, inv.nr. 150.

Transcription of the diary of Gertje Woutera van Slooten-Verwijs, Tresoar Leeuwarden, Familiearchief Van Slooten, toegangsnr. 336, inv.nr. 202.

\section{Printed sources}

Da Costa, Hanna. Dagboekje van Hanna da Costa-Belmonte. Ed., with commentary, O.W. Dubois (Heerenveen 2000).

Van der Meer, J.K.H., Lotte van de Pol, J. Bos. Van de prins geen kwaad. De dagboeken van S.P.A. van Heiden Reinestein kamerheer en drost 1777-1785 (Assen 2007).

\section{Secondary sources}

Baggerman, Arianne. "Lost Time. Temporal Discipline and Historical Awareness in Nineteenth-century Dutch Egodocuments." Eds. Michael Mascuch, Rudolf Dekker, and Arianne Baggerman. Controlling Time and Shaping the Self. Developments in Autobiographical Writing Since the Sixteenth Century. Leiden and Boston: Brill, 2011. 455-541.

Bakker, Nelleke, Jan Noordman, and Marjoke Rietveld-van Wingerden. Vijf eeuwen opvoeden in Nederland. Idee en praktijk: 1500-2000. Assen: Van Gorcum, 2006.

Catalano, Amy J. A Global History of Child Death. Mortality, Burial, and Parental Attitudes. New York: Peter Lang, 2015.

Clarke, Elisabeth. "'A heart terrifying Sorrow': the Deaths of Children in Seventeenth Century Women's Manuscript Journals." Eds. Gillian Avery and Kimberley Reynolds. Representations of Childhooth Death. New York: MacMillan Press, 2000. 65-86.

Dekker, Rudolf. Uit de schaduw in 't grote licht. Kinderen in egodocumenten van de Gouden Eeuw tot de Romantiek. Amsterdam: Wereldbibliotheek, 1995.

Dekker, Rudolf. "Childhood in Dutch Autobiographies, 1600-1850. Changing Memory Strategies.” Paedagogica Historica 32.1 (1996): 65-76.

Dekker, Rudolf. "Egodocuments in the Netherlands from the Sixteenth to the Nineteenth Century." Dutch Crossing 23:2 (1999): 255-285. DOI: 10.1080/03096564.1999.11784118.

Dekker, Rudolf. Childhood, Memory and Autobiography in Holland: From the Golden Age to Romanticism. London: Macmillan, 2000.

Dekker, J.J.H. Educational Ambitions in History. Childhood and Education in an Expanding Educational Space from the Seventeenth to the Twentieth Century. Frankfurt am Main etc.: Peter Lang, 2010.

Engelen, Theo. Van 2 naar 16 miljoen mensen. Demografie van Nederland, 1800-nu. Amsterdam: Boom, 2009.

Gerhalter, Li. "Materialitäten des Diaristischen." L'Homme 24.2 (2013): 53-71.

Goltstein, Alexander van. De vertrouwde van mijn hart: Het dagboek van Alexander van Goltstein (1801-1808). Ed. Jurgen Limonard. Hilversum: Verloren, 1994.

Groenendijk, L.F. and F.A. van Lieburg. Voor edeler staat geschapen. Levens- en sterfbedbeschrijvingen van gereformeerde kinderen en jeugdigen uit de 17e en 18e eeuw. Leiden: Groen, 1991.

Groenendijk, Leendert F., Fred A. van Lieburg, and John Exalto. "'Away with All My Pleasant Things in the World...': Model Death-Bed Accounts of Two Young Victims of the Plague of 1664 in the Dutch Town of Leyden." Paedagogica Historica 46.3 (2010): 271-288. DOI:10.1080/00309230902943910.

Hallgrimsdottir, Gudny. "Material without Value?: The Recollections of Guðrún Ketilsdóttir." Eds. Anna Kuismin and M. J. Driscoll. White Field, Black Seeds: Nordic Literacy Practices in the Long Nineteenth Century. Helsinki: Finnish Literature Society, 2013. 134-145. 
Hochschild, Arlie. The Managed Heart: Commercialization of Human Feeling. Berkeley: University of California Press, 1983.

Jalland, Patricia. Death in the Victorian Family. Oxford: Oxford University Press, 1996.

Jolly, Margaretta, ed. Encyclopedia of Life Writing: Autobiographical and Biographical Forms. London etc.: Fitzroy Dearborn, 2001.

Koning, W. "De Boissevains in brieven: Een case study naar de relatie tussen vaders en zoons uit de gegoede burgerij in negentiende-eeuws Amsterdam." Skript Historisch Tijdschrift 32.3 (2014): 144-156.

Lejeune, Philippe. On Diary. Honolulu: University of Hawai’i Press, 2009.

Lejeune, Philippe. Aux origines du journal personnel: France, 1750-1815. N.P.: Honoré Champion, 2016.

Lindeman, Ruud, Arianne Baggerman, Rudolf Dekker, Yvonne Scherf, eds. Egodocumenten van Nederlanders uit de zestiende tot begin negentiende eeuw: Repertorium. Amsterdam: Panchaud, 2016.

Mathijsen, Marita. De gemaskerde eeuw. Amsterdam: Querido, 2003.

Millim, Anne-Marie. The Victorian Diary: Authorship and Emotional Labour. London: Routledge 2016.

Piller, Gudrun. "Private Body-What Do Self-Narratives Bring to the History of the Body?" Eds. Claudia Ulbrich, Kaspar von Greyerz and Lorenz Heiligensetzer. Mapping the 'I'. Research on Self-Narratives in Germany and Switzerland. Leiden/Boston: Brill, 2015. 76-94.

Poppel, F. van, and E. Beekink. "Mapping Infant Mortality in the Netherlands: Its History and Current Status.” Eds. W.H. Hubbard, K. Pitkänen, J. Schlumbohm, S. Sogner, G. Thorvaldsen and F. van Poppel. Historical Studies in Mortality Decline. Oslo: Novus Forlag, 2002. 113-134. http://www.nidi.nl/shared/content/output/2002/dnva-2002-mortalitydecline-vanpoppel.pdf.

Poppel, Frans van, and Peter Ekamper. "Historische ontwikkeling van de sterfte in Nederland.” Eds. A.H.P. Luijben and G.J. Kommer. Tijd en toekomst. Deelrapport van de Volksgezondheid Toekomst Verkenning 2010 van gezond naar beter. Houten: Bohn Stafleu Van Loghum, 2010. 20-25.

Ruberg, Willemijn. Conventionele correspondentie. Briefcultuur van de Nederlandse elite, 1770 1850. Nijmegen: Van Tilt, 2005.

Scheer, Monique. "Are Emotions a Kind of Practice (and is that what makes them have a History)? A Bourdieuian Approach to Understanding Emotion." History and Theory 51 (2012): 193-220. DOI:10.1111/j.1468-2303.2012.00621.x.

Schwartz, Joan M., and Terry Cook. "Archives, Records, and Power: The Making of Modern Memory.” Archival Science 2.1-2 (2002): 1-19. DOI:10.1007/BF02435628.

Sicking, J.M.J. "Bewustzijnsweergave in Nederlandse romans uit de negentiende eeuw." De nieuwe taalgids 82 (1989) 289-304. http://www.dbnl.org/tekst/_taa008198901_01/_ taa008198901_01_0034.php, accessed 11 January 2016.

Sliggers ed., B.C. Naar het lijk. Het Nederlandse doodsportret 1500-heden. Exhibition Catalogue Teylers Museum Haarlem, Zutphen 1998.

Stavenuiter, M.M.J. "Vaders. Vaderschap in historisch perspectief. Afstand of betrokkenheid? Vaderschap in de negentiende eeuw." Kind en adolescent 19.1 (1998): 22-26.

Sturkenboom, D. ““...want ware zielesmart is niet woordenrijk’. Veranderende gevoelscodes voor nabestaanden 1750-1988." Ed. A. van der Zeijden. Cultuurgeschiedenis van de dood. Amsterdam/Atlanta: Rodopi, 1990. 84-113.

Tomhave Blauvelt, Martha. "The Work of the Heart. Emotion in the 1805-35 Diary of Sarah Connell Ayer." Journal of Social History 35.3 (2002): 577-592.

Tosh, John. A Man's Place: Masculinity and the Middle-class Home in Victorian England. New Haven/London: Yale University Press, 1999. 
Treffers, P.E. "Zuigelingensterfte en geboorten in de 19e en begin 20e eeuw." Nederlands Tijdschrift voor Geneeskunde 152.51/52 (2008): 2788-2794.

Vandezande, Mattijs and Koen Matthijs. "Sibling en scholing. Het effect van geslacht en van gezinssamenstelling op geletterdheid in Nederland in de tweede helft van de negentiende eeuw." Tijdschrift voor Sociale en Economische Geschiedenis 6.4 (2009): 70-86. DOI: http:/ / doi. org/10.18352/tseg.470.

Vanmeenen, Anne-Flor and Anne-Mie Havermans. De dood in kinderschoenen. Gent: Academia Press, 2011.

Vermeer, Leonieke. "Tiny Symbols tell Big Stories. Naming and Concealing Masturbation in Diaries (1660-1940)." European Journal of Life Writing 6 (2017): 101-134. http://ejlw.eu/ article/view/209/426. DOI: http://dx.doi.org/10.5463/ejlw.6.209.

Wilson, Stephen. "The Myth of Motherhood a Myth: The Historical View of European ChildRearing." Social History 9.2 (1984): 181-198. DOI:10.1080/03071028408567590.

\section{ABOUT THE AUTHOR}

Leonieke Vermeer is Assistant Professor of Modern History at the University of Groningen. She studied piano at the Prins Claus Conservatory (1999) and History (2004, cum laude) at the University of Groningen. She wrote her thesis Geestelijke lenigheid. De relatie tussen literatuur en natuurwetenschap in het werk van Frederik van Eeden en Felix Ortt, 1880-1930 ('Mental sinuosity', 2010) on the relationship between literature and science. She is the author of several journal articles and other publications, such as the co-authored book Utopianism and the Sciences, 1880-1930 (Leuven: Peeters, 2010). Her recent research focuses on diary practices, illness experiences in self-narratives and the history of emotions in the 19th century. She is editor of the European Journal of Life Writing and of the interdisciplinary, peer-reviewed journal De Moderne Tijd. De Lage Landen, 1780-1940.

\section{NOTES}

1 "De $10^{\text {de }}$ maart 1826 des avonds ten half elf uuren bevallen van een achtmaands kindje, een welgeschapen zoon, die wij hadden gehoopt te noemen Isaäc Jacob, maar dat lieve kind heeft de groote God in Zijne genade en voorzienigheid in Zijn heerlijke Koningrijk overgenomen [...]." Da Costa 2000, 39.

2 Philippe Aries, Jan Hendrik van den Berg, Lloyd DeMause, Lawrence Stone, Edward Shorter and Elisabeth Badinter defended the "black legend". Proponents of the "white legend" were Shulamith Shahar, Alan Macfarlane, Harry Peeters and Linda Pollock. For a discussion of the debate, see: Dekker 2000.

3 http://www.egodocument.net/ (accessed 25 May 2018).

4 Rudolf Dekker mainly studied diaries from before 1800 (Dekker 2000).

5 This method of studying self-narratives by using 'model sources' and 'additional sources' is proposed by: Piller 2015, 92-93.

6 "Wel wordt aan u nog menig traan gewijd/Lief kindje dat we in 't vochtig zand begroeven Maar ziet gij soms nog neder op ons, droeven/Nu gij bij God een vrolijk Engel zijt?" Nicolaas Beets, "Aan een gestorven kind" (1840) as cited by Mathijsen 2003, 122.

7 "We zijn er diep door getroffen en deze ongelukkige gebeurtenis grijpt vooral mijn vrouw aan, aan wie dit kind bijzonder gehecht was." (August 9). 'Het gemis van mijn 
kind veroorzaakt hevig verdriet bij mijn vrouw.' (August 10). Van der Meer et al. 2007,140 .

8 "den 17 december is mevrouw zeer gelukkig verlost van een zoon, die bij de geboorte vrij gesond scheen, dan met de sesden dag kreeg het sulken geweldige stuipen, dat hij er de 7 de dag zijnde den 24 december onder besweek, wij hadden dus ongeluk dit kindje, pas 8 daagen oud, weederom te verliesen, het is in de Aa kerk begraaven [...]. Met 6 weeken was mijn lieve vrouw wederom hersteld en deed haar uitgang in de avondkerk [...]." Kroniek van de familie, 1756-1848, aangelegd en bijgehouden door Reneke de Marees van Swinderen van Allersma 1827, vervolgens bijgehouden door zijn zoon Wicher Meynart de Marees van Swinderen, 1818-1848, Groninger Archieven, Familiearchief Van Swinderen en De Marees van Swinderen, toegangsnr. 552, inv.nr. 150.

9 De Clercq does not agree with the Mennonites who practiced adult baptism, reasoning that infants and young children could not decide of their own volition to be baptised.

10 "God moge hij als engel ons eens het sterven ligt maken." Willem de Clercq, Dagboek XI, 1824, http://resources.huygens.knaw.nl/retroboeken/declercq (accessed 25 May 2018). Subsequent quotes also from this diary.

11 "Het was akelig \& het lieve kind scheen stervende. Daar zaten wij bij hem. Een vrouw is dan gezegend, zij is zoo regt waar zij zijn moet om te lijden \& te helpen integeven, duizenderlei dingen te bezorgen, een man zit daar zoo elendig."

12 "Oom v Heuk kwam ook \& redeneerde mannelijk hartelijk \& krachtig vooral ook met opzigt tot Lina."

13 Diary of Hendrik Kikkert, Gemeentearchief Vlaardingen, HS 897. Subsequent quotes also from this diary.

14 "zeer ongesteld, en op het punt om eene Zenuw-Zinking ziekte te krijgen."

15 "want gaarne wil ik mijn hart nog eens uitstorten op dit papier-om mij naderhand bij de herlezing daarvan te verheugen of er troost in te vinden."

16 "Onze zeven kinderen zijn nog allen in leven, hoezeer ik nu zit te waken bij Mietje en Keetje die beiden aan de mazelen ziek liggen, zo als Cornelis voor eenige dagen daar aan leed."

17 "Daar zit ik nu, naast het sterfbedje van mijnen jongsten lieveling Hendrik, heden voor tien weeken schonk Gods liefde ons in hem een allerschoonst en gezond kind, eenige weeken bleef het voorspoedig, tot het nu sints 14 dagen en vooral in de laatste 2 dagen verminderde en uitteerde, waarschijnlijk ten gevolge van een of ander gebrek in de ingewanden of in het hart, en nu reeds gedurende den geheelen avond ligt te zieltogen:daar ligt dan nu dat schoone bloempje, onzer oogen lust, onzer aller lieveling-door de koude hand des doods aangeraakt, nog eenige oogenblikken en het is niet meer."

18 "Ik heb daar zóó zijne oogjes toegedrukt, hij is gestorven-zijne brave moeder is, afgetobt-ingesluimerd. Ik ga haar wekken omte [sic] samen te weenen en te bidden-en vooral om God te danken voor al het goede dat ons nog overblijft."

19 A soliloquy is spoken by a person who is alone or acts as though he or she is alone. It is a kind of talking to oneself, not intended to affect others. Sicking 1989, 290-291.

20 "Geliefd kind! Ik staar U na in de Eeuwigheid, ik beween U als vader, Uw sterven doet mijn hart zeer."

21 "ik berust in Gods wijs en liefderijk bestuur. Uw rein onschuldig Kinder-zieltje zal binnen weinige ogenblikken opvaren naar den Hemel bijJezus den kindervriend—bij God, Uwen en mijnen Vader, en dan zult Gij eeuwig zalig wezen." [...] "O! Hoe menigmaal zult Gij welligt nog op ons in liefde nederzien, voor ons bidden als leed of ramp of verzoekingen ons bedreigen."

22 "Dat de gedachte aan U mijn dierbaar Kind en de vaste hoop van U eenmaal in de Zalige Eeuwigheid wedertezien-mij nooit verlate, en nu—vaarwel dan lieveling—vaarwel tot in de Eeuwigheid." 
23 "Het kind werd volkomen present naarmate de doods-benauwdheid toenam. Benauwend was ook het ouderhart iedere ademhaling en ieder leedvol oog, dat zij tot ons opsloeg." Dagboek Abraham Rutgers van der Loeff, http://www.rutgersvanderloeff.nl/dagboek/ html/index.html (accessed 25 May 2018). Subsequent quote also from this diary.

24 "Thuiskomende vond ik Romelia nog even kalm en geloovig redeneerende en wij hadden samen nog nuttige en stichtelijke gesprekken."

25 "Zijne bijzondere uitredding en herstelling." Da Costa 2000, 39. Subsequent quotes also from this diary.

26 "De almachtige had dit tijdstip bepaald. [...] Zeer groot was deze strijd voor mij, voordat ik dit dierbaar kind konde overgeven."

27 Diary Hanna da Costa-Belmonte, Special Collections of the University of Amsterdam, ref. nr. RA H: XVIII, cahier 4. Subsequent quote also from this diary.

28 "De visites, brieven en kaartjes waren menigvuldig, soms vertroostend, maar ook zeer afmattend."

29 Dagboekaantekeningen J.D. Waller, met verslag van de ziekte van zijn kindje, 1840 1849, Stadsarchief Amsterdam, Archief van Waller-Pierson, toegangsnr. 1092, inv.nr.14.

30 The oldest known German-language "Müttertagebuch" (mother's diary) hitherto dates from 1888. Gerhalter 2013, 63.

31 "Zijn vierde tand. Hij is vrolijk en ziet heel gezond, gaat dagelijks zo veel mogelijk uit." Transcriptie van dagboekjes van Gertje Woutera van Slooten-Verwijs, Tresoar Leeuwarden, Familiearchief Van Slooten, toegangsnr. 336, inv.nr. 202. 